\title{
TINJAUAN NORMATIF TERHADAP ONLINE DISPUTE RESOLUTION SEBAGAI METODE PENYELESAIAN SENGKETA E-COMMERSE
}

\author{
Daniel Simamora \\ Email: danielsmm@gmail.com
}

\section{Abstract}

The era of the introduction of free markets and free competition has changed the direction of business, trade and service transaction activities which previously shifted to electronic and online media known as ECommerse. This has taken a lot of time, both in terms of efficiency over a wide range. However, the frequency of disputes is also violated. Disputes that occur can lead out of non-litigation (outside the Court) or are often called Alternative Dispute Resolution (APS). Unfortunately, the obligation of the disputing parties directly in the implementation of conventional APS is certainly difficult. So that we need a solution that can be done quickly, cheaply and effectively without hindering the business activities of the parties. One of the breakthroughs is using the online APS model or known as the Online Dispute Resolution (ODR). The magnitude of the potential for e-commerce disputes over several parts. In the Market Place itself, the factors that cause disputes between sellers and buyers in electronic transactions include: a) inappropriate quality of goods; b) the information provided is scanty, c) unsuitable goods, d) fraud. B) Tax (cybertax), C) Audit trail D) There is no global law that regulates the internet E) Privacy 2) Potential disputes The ODR concept is regulated in detail and firmly, but that does not mean it cannot be regulated in Indonesia, because Indonesia provides freedom to contract and choose the dispute resolution forum. This can be seen in Article 1338 of the Civil Code and in Article 18 of Law Number 11 of 2008 concerning Electronic Information and Transactions. Regarding the implementation of online mediation, it is contained in the rules of Article 5 paragraph (3) PERMA No. 1 of 2016 
concerning Mediation Procedures in Courts. Meanwhile, the loophole for conducting online arbitration can be seen from the provisions of Law Number 30 of 1999 concerning Arbitration and Alternative Dispute Resolution Article 4 paragraph (3). Electronic documents and the validity of documents and electronic signatures have been regulated in Article 5 of the ITE Law.

\section{Keywords: ODS Review, Methods, Dispute Resolution}

\section{Abstrak}

Dimulainya era pasar bebas dan persaingan bebas telah merubah arah aktifitas transaksi bisnis, dagang, jasa yang sebelumnya konvensional beralih ke media elektronik maupun online yang dikenal dengan $E$ Commerse. Hal ini telah membawa banyak kemudahan, baik dari segi efisiensi waktu dalam jangakauan yang luas. Namun hal ini juga memicu meningkatnya frekuensi sengketa. Sengketa yang terjadi dapat diselesaikan melalui mekanisme nonlitigasi (diluar Pengadilan) atau sering disebut Alternatif Penyelesaian Sengketa (APS). Sayangnya keharusan para pihak yang bersengketa untuk bertemu secara langsung dalam pelaksanaan APS konvensional tentu menyulitkan. Sehingga diperlukan sebuah metode penyelesaian sengketa yang dapat dilakukan dengan cepat, murah dan efektif tanpa menghambat kegiatan bisnis para pihak. Salah satu terobosannya dengan menggunakan model APS online atau dikenal dengan istilah Online Dispute Resolution (ODR). Besarnya potensi sengketa e-commerse terjadi atas beberapa bagian. Didalam Market place sendiri faktor-faktor yang sering menyebabkan sengketa antara penjual dan pembeli dalam transaksi elektronik, antara lain: a)kualitas barang yang tidak sesuai; b) informasi yang diberikan sedikit, c) barang tidak sesuai, d) penipuan. B) Pajak (cybertax), C) Audit trail D)Belum ada undang-undang global yang mengatur internet E)Privacy 2)Potensi sengketa Konsep ODR memang belum diatur secara rinci dan tegas, namun bukan berarti tidak dapat diperlakukan di Indonesia, karena 
Indonesia memberikan kebebasan berkontrak dan memilih forum penyelesaian sengketanya. Hal ini dapat dilihat pada Pasal $1338 \mathrm{KUH}$ Perdata dan pada Pasal 18 Undang-Undang Nomor 11 Tahun 2008 tentang Informasi dan Transaksi Elektronik. Mengenai pelaksanaan mediasi online terdapat dalam aturan Pasal 5 ayat (3) PERMA No. 1 tahun 2016 tentang Prosedur Mediasi di Pengadilan. Sedangkan celah untuk melakukan arbitrase online dapat dilihat dari ketentuan Undang-Undang Nomor 30 Tahun 1999 Tentang Arbitrase dan Alternatif Penyelesaian Sengketa Pasal 4 ayat (3). Dokumen elektronik dan sahnya suatu dokumen serta tanda tangan elektronik, telah diatur dalam UndangUndang ITE Pasal 5.

\section{Kata Kunci : Tinjauan ODS, Metode, Penyelesaian Sengketa}

\section{Pendahuluan}

Internet telah membentuk masyarakat dengan kebudayaan baru, saat ini hubungan masyarakat dalam dimensi global tidak lagi dibatasi oleh batas-batas teritorial negara (borderless). Hadirnya internet dengan segala fasilitas dan program yang menyertainya, seperti: e-mail, chatting video, video teleconference, dan situs website $(w w w)$, telah memungkinkan dilakukannya komunikasi global tanpa mengenal batas. ${ }^{1}$

Kebiasaan yang sebelumnya dilakukan secara langsung dengan tatap muka sekarang sudah berubah dengan menggunakan internet menjadi transaksi tanpa tatap muka atau jarak jauh yaitu transaksi elektronik yang dilakukan menggunakan media elektronik dan jaringan internet sehingga dalam keadaan online atau saling terhubung. Hal ini juga memegang peranan penting dalam proses perkembangan setiap elemen saat ini. Pengaruh arus globalisasi dan perdagangan bebas yang didukung oleh kemajuan teknologi komunikasi dan informasi telah memperluas ruang gerak arus transaksi barang, baik dalam negeri sendiri

\footnotetext{
${ }^{1}$ Efa Laela Fakhriah, Bukti Elektronik Dalam Pembuktian Perdata, Bandung: PT Alumni, 2011, h. 4-5.
} 
maupun yang masuk dari luar negeri. Dalam zaman modern ini perdagangan adalah pemberian perantaraan kepada produsen dan konsumen untuk membelikan dan menjualkan barang-barang yang memudahkan dan memajukan pembelian dan penjualan itu. ${ }^{2}$

Mengamati perdagangan di Indonesia saat ini, transaksi dagang di Internet merupakan tempat baru yang semakin berkembang dan digemari .Berdasarkan data yang dilansir Masyarakat Telematika Indonesia (2016) menunjukkan potensi besar. Pengguna internet Indonesia berjumlah sekitar 88,1 juta orang (34\% dari populasi), pengguna telepon seluler sekitara 308,2 juta pengguna (121\% dari populasi) dan pengguna ponsel cerdas sekitar 63,4 juta pengguna $\left(24,7 \%\right.$ dari populasi) ${ }^{3}$ Hal ini menunjukkan bahwa pengaruh akses internet dalam dunia perdagangan Indonesia sangat memiliki dampak dalam perekonomian, baik bagi seluruh kalangan. Dengan perkembangan teknologi dalam bidang perdagangan yang memanfaatkan media internet melalui sistem elektronik ini muncul istilah dikenal dengan istilah Electronic Commerce (disingkat ecommerce).

E-commerce merupakan media yang digunakan sebagai transmisi (telekomunikasi) yang di dalamnya mancakup pertukaran, pembelian, dan penjualan suatu produk atau jasa yang menggunakan transportasi, baik secara fisik maupun digital dari lokasi ke lokasi. ${ }^{4}$ Dalam bahasa sederhana E-Commerce dapat diartikan dengan transaksi elektronik. Perkembangan e-commerce diatur di dalam Undang-undang No. 11 Tahun 2008 dan Undang-Undang No. 19 Tahun 2016 Tentang Informasi dan Transaksi Elektronik (yang selanjutnya disingkat UU ITE) dan

${ }^{2}$ Prof. Drs. C.S.T. Kansil,SH dan Christine S.T. Kansil, S.H., M.H,Pokok-Pokok Pengetahuan Hukum Dagang Di Indonesiaedisi Kedua,Sinar Grafika,2002, h.13. Kekuatan

${ }^{3}$ Fadhly Fauzi Rahman, Transaksi E-Commerce RP 250 T, Mendag: RI Punya

Perdagangan Digital Global, https://finance.detik.com diakses pada tanggal 07 September 2019 pukul 00:45

${ }^{4}$ Marilyn Greenstein and Miklos Vasarhelyi, Electronic Commerce (New YPork McGraw Hill, 2002), h.2. 
Peraturan Pemerintah No. 82 Tahun 2012 tentang Penyelenggaraan Sistem dan Transaksi Elektronik (yang selanjutnya disingkat PP PSTE).

Obyek e-commerce adalah barang atau jasa yang diperjualbelikan oleh penjual kepada setiap orang yang membeli barang dan jasa melalui e-commerce. Namun tidak semua barang atau jasa dapat diperjual belikan dalam e-commerce. Undang-Undang Informasi dan Transaksi Elektronik dan Undang-Undang Perlindungan Konsumen (selanjutnya disingkat UUPK) tidak mengatur mengenai syarat-syarat barang atau jasa yang diperbolehkan untuk diperjualbelikan dalam e-commerce.UU ITE tidak mengatur mengenai kriteria barang yang boleh diperdagangkan dalam transaksi e-commerce, namun Pasal 9 UU ITE mewajibkan penjual untuk menyediakan informasi yang lengkap dan benar berkaitan dengan produk yang ditawarkan dan Pasal 28 Ayat (1) melarang penyebaran berita bohong dan menyesatkan yang mengakibatkan kerugian pembeli dalam transaksi elektronik

Beberapa tahun terakhir perdagangan online semakin marak terjadi di Indonesia. Ribuan situs e-commerce (perdagangan elektronik) pun muncul untuk menjawab kebutuhan masyarakat dalam berbelanja online. ${ }^{5}$ Sistem pasar bebas dan persaingan bebas antar negara dalam perdagangan online tersebut mengakibatkan kegiatan transaksi bisnis berkembang cepat. Adanya ratusan ribu transaksi bisnis setiap hari, intensitas transaksi bisnis baik domestik maupun internasional diperkirakan meningkat setiap harinya, maka akan memicu meningkatnya frekuensi sengketa. Beragam sengketa yang timbul dari kegiatan bisnis atau aktivitas komersial itu secara umum disebut sengketa bisnis atau sengketa komersial. ${ }^{6}$

${ }^{5}$ Andina Librianty, Ketimbang Sibuk Bersaing, Shopee Utamakan Layanan Konsumen,

http://tekno.liputan6.com diakses pada tanggal 07 September 2019 pukul 01:02.

${ }^{6}$ Eman Suparman, Pilihan Forum Arbitrase dalam Sengketa Komersil untuk Penegakan Keadilan(Jak arta: Tatanusa, 2004), h. 5. 
Yayasan Lembaga Konsumen Indonesia (YLKI) mencatat pengaduan dari konsumen terkait belanja online (online shop) merupakan yang paling banyak diterima selama 2017. Ketua Pengurus Harian YLKI Tulus Abadi mencatat sepanjang 2017, lembaga tersebut menerima 642 pengaduan, yang 16 persen di antaranya atau 101 pengaduan terkait transaksi belanja online. $^{7}$

Sengketa yang terjadi dapat diselesaikan melalui mekanisme litigasi (Pengadilan) maupun nonlitigasi (diluar Pengadilan) atau sering disebut Alternatif Penyelesaian Sengketa (APS). Dalam penyelesaian sengketa di luar pengadilan, pihak yang bersengketa tidak melalui proses hukum formal yang seringkali mahal dan memakan waktu. Para pihak cukup mengajukan perkaranya pada pihak ketiga untuk menyelesaikan persengketaan. Selain itu hendaknya segala sengketa dapat diselesaikan dengan asas kekeluargaan, karena budaya bangsa Indonesia menjunjung tinggi jiwa kooperatif dalam penyelesaian konflik atau sengketa yang merupakan perwujudan sila keempat pancasila yaitu musyawarah untuk mufakat. Di mana tujuan dari musyawarah tersebut demi terwujudnya keadilan sosial bagi masyarakat Indonesia.

Mengenai dasar diadakannya ADR diatur dalam Undang-Undang Nomor 30 tahun 1999 tentang Arbitrase dan Alternatif Penyelesaian Sengketa (UU Arbitrase dan APS). Di mana dalam Pasal 1 butir 10 UU Arbitrase dan APS menyebutkan bahwa: "Alternatif Penyelesaian Sengketa adalah lembaga penyelesaian sengketa atau beda pendapat melalui prosedur yang disepakati para pihak, yakni penyelesaian di luar pengadilan dengan cara konsultasi, negosiasi, mediasi, konsiliasi, atau penilaian ahli"

${ }^{7}$ M. Agus Yozami, Rujukan Aturan Perundang-Undangan Bagi Konsumen Yang Dirugikan Online Shop Pemerintah Sudah Saatnya Mengesahkan Rancangan

Pemerintah (RPP) Tentang Perdagangan Elecktronik Yang Menjadi Payung Teknis Untuk Operasional Belanja Online, www.hukumonline.com diakses pada tanggal 07 September 2019 pukul 01:21 
Sayangnya keharusan para pihak yang bersengketa untuk bertemu secara langsung dalam pelaksanaan ADR konvensional tentu menyulitkan. Sehingga diperlukan sebuah metode penyelesaian sengketa yang dapat dilakukan dengan cepat, murah dan efektif tanpa menghambat kegiatan bisnis para pihak. Salah satu terobosannya dengan menggunakan model ADR online atau dikenal dengan istilah Online Dispute Resolution (ODR), yang dapat dilakukan melalui media internet dan jika diperlukan pertemuan face to face dapat dilakukan secara audiovisual melalui media video-conferencing. ${ }^{8}$ Dengan begitu sengketa dapat diselesaikan dimana saja. Umumnya para pihak lebih menyukai jenis penyelesaian sengketa ini karena sifat keputusannya yang final dan binding. Meskipun, terdapat suatu fenomena baru dimana putusan ADR online yang bersifat non binding. Penyelesaian sengketa melalui ODR (Online Dispute Resolution) belum diatur di Indonesia. Salah satu tujuan dari adanya ODR yaitu keinginan untuk meningkatkan kepercayaan masyarakat dalam perdagangan secara online dengan menyediakan penyelesaian sengketa yang cepat dan kepastian hukum lintas geografi, bahasa dan juridiksi hukum yang berbeda.

Beberapa negara telah menerapkan dan memanfaatkan ODR, namun keberadaan ODR di Indonesia belum diterapkan, sehingga secara yuridis penggunaan mekanisme penyelesaian sengketa secara online (ODR) belum dirumuskan. Namun penyelesaian sengketa dengan cara online akan membuat suatu terobosan baru di bidang penyelesaian sengketa di Indonesia.

Seolah setuju dengan adanya ODR Pablo Cortés dalam teorinya menyatakan: "Online Dispute Resolution (ODR) is often referred as a form of ADR which takes advantage of the speed and convenience of the Internet and ICT. ODR is the best (and often the only) option for enhancing

8 Moch. Basarah, Prosedur Alternatif Penyelesaian Sengketa Arbitrase Tradisional Dan Modern (Online), h. 91. 
the redress of consumer grievances, strengthening their trust in the market, and promoting the sustainable growth of e-commerce"

Menanggapi adanya ODR yang telah lebih dulu diterapkan oleh beberapa negara bahkan situs belanja online, Pemerintah telah menyusun Draft PeraturanPemerintah Republik Indonesia tentang Transaksi Perdagangan Melalui Sistem Elektronik. Di mana dalam Pasal 79 ayat (1) berbunyi: "Dalam hal terjadi sengketa dalam transaksi perdagangan melalui sistem elektronik, para pihak dapat menyelesaikan sengketa melalui pengadilan atau melalui mekanisme penyelesaian sengketa lainnya", kemudian dalam Pasal 79 ayat (2) berbunyi: "Penyelesaian sengketa transaksi perdagangan melalui sistem elektronik sebagaimana dimaksud pada ayat (1) dapat diselenggarakan secara elektronik (Online Dispute Resolution) sesuai ketentuan peraturan perundang-undangan".

Terlihat pada Pasal 79 ayat (2) bahwa terdapat kemungkinan penyelesaian sengketa secara elektronik ODR (Online Dispute Resolution). Namun, tidak terdapat penjelasan lebih lanjut terkait ODR itu sendiri atas pasal ini. Sayangnya sampai sekarang Draft Peraturan Pemerintah Republik Indonesia tentang Transaksi Perdagangan Melalui Sistem Elektronik belum juga disahkan. Ini menunjukkan adanya uncompletely of norm atau ketidak lengkapan hukum.

Selain itu dalam UU No. 30 tahun 1999 tentang Arbitrase dan Alternatif Penyelesaian Sengketa, celah untuk melakukan arbitrase online dapat dilihat dari ketentuan Pasal 4 ayat (3) sebagai berikut: "Dalam hal disepakati penyelesaian sengketa melalui arbitrase terjadi dalam bentuk pertukaran surat, maka pengiriman teleks, telegram, faksimili, e-mail atau dalam bentuk sarana komunikasi lainnya, wajib disertai dengan suatu catatan penerimaan oleh para pihak". Dengan demikian, maka para pihak tidak diwajibkan untuk hadir selama proses arbitrase dengan syarat para pihak telah mengadakan kesepakatan sebelumnya. 2011), h. 1

${ }^{9}$ Pablo Cortés, "What is Online Dispute Resolution?," CSLS Oxford (Oktober, 
Seolah senada pada Pasal 5 ayat (3) PERMA No. 1 tahun 2016 tentang Prosedur Mediasi di Pengadilan menyebutkan "Pertemuan Mediasi dapat dilakukan melalui media komunikasi audio visual jarak jauh yang memungkinkan semua pihak saling melihat dan mendengar secara langsung serta berpartisipasi dalam pertemuan". Hal ini didukung oleh Pasal 6 ayat (2) yang berbunyi "Kehadiran Para Pihak melalui komunikasi audio visual jarak jauh sebagaimana dimaksud dalam Pasal 5 ayat (3) dianggap sebagai kehadiran langsung".

\section{Tinjauan Pustaka}

\section{Prinsip E-Commerce}

E-commerce atau Perdagangan elektronik (bahasa Inggris: electronic commerce atau e-commerce) adalah penyebaran, pembelian, penjualan, pemasaran barang dan jasa melalui sistem elektronik seperti internet atau televisi, www, atau jaringan komputer lainnya. E-commerce dapat melibatkan transfer dana elektronik, pertukaran data elektronik, sistem manajemen inventori otomatis, dan sistem pengumpulan data otomatis. $^{10}$ Sebagaimana yang diatur dalam Pasal 1 angka 24 UU Perdagangan, perdagangan melalui sistem elektronik adalah perdagangan yang transaksinya dilakukan melalui serangkaian dan prosedur elektronik.

Dalam Undang-Undang ITE dan PP PSTE transaksi elektronik adalah perbuatan hukum yang dilakukan dengan menggunakan komputer, jaringan komputer, dan/atau media elektronik lainnya. Transaksi sendiri menurut Kamus Besar Bahasa Indonesia adalah persetujuan jual beli antara dua pihak. Pihak-pihak dalam transaksi jual beli elektronik, sama saja dengan transaksi yang terjadi seperti biasanya, dimana dalam berbelanja ini ada seorang penjual dengan

${ }^{10}$ Fauyhi Eko Nugroho, Perancangan Sistem Informasi Penjualan Online Studi Kasus Tokoku, Jurnal Simetris Vol. 7 No 2 November, Tangerang: Universitas Muhammadiyah Tangerang, 2016, h. 718. 
memberikan informasi yang lengkap dan benar berkaitan barang yang dijualnya sesuai Pasal 9 Undang-Undang ITE.

Pasal 1457 KUH Perdata menyebutkan bahwa jual beli adalah suatu persetujuan dengan mana pihak yang satu mengikatkan dirinya untuk menyerahkan suatu kebendaan dan pihak yang satu lain untuk membayar harga yang telah dijanjikan. Perjanjian yang dinyatakan sah adalah suatu perjanjian yang memenuhi empat syarat yang terdapat dalam Pasal 1320 KUH Perdata, yaitu:

1. Adanya kesepakatan kedua belah pihak;

2. Kecakapan untuk melakukan perbuatan hukum;

3. Adanya objek tertentu, dan

4. Adanya sebab yang halal. Asas-asas pokok yang berlaku dalam kontrak yaitu: ${ }^{11}$

1. Asas kebebasan berkontrak

2. Asas konsensualisme

3. Asas pacta sunt servanda

4. Asas iktikad baik

Kontrak elektronik dalam Pasal 47 Ayat (2) PP PSTE adalah:

1. Terdapat kesepakatan para pihak;

2. Dilakukan oleh subjek hukum yang cakap atau yang berwenang mewakili sesuai dengan ketentuan peraturan perundang-undangan;

3. Terdapat hal tertentu; dan

4. Objek transaksi tidak boleh bertentangan dengan peraturan perundang-undangan,kesusilaan, dan ketertiban hukum.

Kontrak Elektronik itu sendiri menurut Pasal 48 Ayat (3) PP PSTE setidaknya

memuat:

1. Data identitas para pihak;

2. Objek dan spesifikasi;

${ }^{11}$ Agus Yudha Hernoko, Hukum Perjanjian Asas Proporsionalitas Dalam Kontrak Komersial, Jakarta: Kencana, 2010, h. 108. 
3. Persyaratan transaksi elektronik;

4. Harga dan biaya;

5. Prosedur dalam hal terdapat pembatalan oleh para pihak;

6. Ketentuan yang memberikan hak kepada pihak yang dirugikan untuk dapat mengembalikan barang dan/atau meminta penggantian produk jika terdapat cacat tersembunyi; dan

7. pilihan hukum penyelesaian Transaksi Elektronik.

Penulis sependapat dengan penjelasan yang diberikan dalam UU ITE, PP PSTE dan KUH Perdata tentang pengertian jual beli, transaksi elektronik sehingga terciptanya suatu kontrak elektronik.

Perdagangan adalah tatanan kegiatan yang terkait dengan transaksi barang dan/atau jasa di dalam negeri dan melampaui batas wilayah negara dengan tujuan pengalihan hak atas barang dan/atau jasa untuk memperoleh, imbalan atau kompensasi sesuai dalam UndangUndang Perdagangan Pasal 1 Ayat (1), pada Ayat (24) menjelaskan perdagangan melalui sistem elektronik adalah perdagangan yang transaksinya dilakukan melalui serangkaian perangkat dan prosedur elektronik.

Industri teknologi informasi melihat kegiatan e-commerce ini sebagai aplikasi dan penerapan dari elektronik bisnis (e-business) yang berkaitan dengan transaksi komersial, seperti: transfer dana secara elektronik, SCM (supply chain management), pemasaran elektronik (emarketing), atau pemasaran online (online marketing), pemrosesan transaksi online (online transaction processing), pertukaran data elektronik; electronic data interchange (EDI) dan lainnya.

Menurut Sutan Remy Sjahdeini, e-commerce adalah kegiatan bisnis yang menyangkut konsumen, manufaktur, service providers, dan pedagang perantara dengan menggunakan jaringan-jaringan komputer yaitu internet.

Beberapa unsur dari e-commerce, yaitu:

1. Ada kontrak dagang. 
2. Kontrak itu dilaksanakan dengan media elektronik.

3. Kehadiran fisik dari para pihak tidak diperlukan.

4. Kontrak itu terjadi dalam jaringan publik.

5. Sistemnya terbuka, yaitu dengan internet.

Kontrak itu terlepas dari batas yuridiksi nasional.

\section{Metode Penelitian}

Penelitian ini memfokuskan pada dua rumusan masalah yaitu faktor yang menyebabkan besarnya potensi sengketa e-commerce dan bagaimana legalitas hukum Online Dispute Resolution (ODR) dalam perspektif hukum positif

Penelitian ini termasuk kedalam jenis penelitian yuridis normatif yaitu dengan cara meneliti bahan pustaka (library research). Pendekatan yang digunakan yaitu pendekatan perundang-undangan (statute approach). Sedangkan bahan hukum yang digunakan yaitu bahan hukum primer, sekunder dan tersier yang kemudian dianalisis

\section{Hasil Penelitian dan pembahasan tentang Tinjauan Normatif Terhadap Online Dispute Resolution Sebagai Metode Penyelesaian Sengketa E-Commerse.}

\section{Konsep Online Dispute Resolution}

Online Dispute Resolution (ODR) adalah cabang penyelesaian sengketa yang menggunakan fasilitas teknologi untuk memberikan penyelesaian terhadap sengketa antara para pihak. ODR dalam hal ini menggunakan negosiasi, mediasi atau arbitrase ataupun kombinasi di antara ketiganya. Dalam hal ini, ODR dikategorikan sebagai bagian dari Alternative Dispute Resolution (ADR). Perbedaannya terletak di mana ODR mengubah pandangan tradisional menjadi penggunaan teknik yang 
inovatif dan teknologi online pada prosesnya. ${ }^{12}$

Pengertian Online Dispute Resolution, yang selanjutnya disebut ODR menurut Melissa Conley Taylor yang dikutip oleh Prof. Dr. Moch Basarah dalam bukunya Prosedur Alternatif Penyelesaian Sengketa: Arbitase Tradisional dan Modern (Online) adalah:

"ODR refers to ADR processes conducted with the assistance of information technology, particularly the internet." ${ }^{13}$

Sedang menurut Ethan Katsh dan Janet Rifkin dalm bukunya Online Dispute Resolution: Resolving Conflicts in Cyberspace menyebutkan:

"Odr draws its main themes and concepts from alternative dispute resolution (adr) processes such as negotiation, mediation and arbitration. Odr uses the opportunities provided by the internet not only to employ these processes in the online environment but also to enhance these processes when they are used to resolve conflicts in offline environments. Odr is a developing field that will change as new online tools and resources are developed. Like adr, however, at its core is the idea of providing dispute resolution in a more flexible and efficient manner than is typical with courts and litigation."14 Dengan kata lain ODR adalah suatu cara penyelesaian sengketa yang dilakukan oleh para pihak yang berada dalam wilayah lintas batas negara (borderless) tanpa harus bertemu muka (face to face).

Perkembangan internet dimulai pada tahun 1969, namun kebutuhan akan ODR tidak muncul sampai awal 1990-an. Selama dua dekade pertama, internet digunakan oleh sejumlah orang dalam jumlah terbatas. Mereka yang memiliki akses Internet dikaitkan dengan militer atau dengan institusi akademik dan bahkan dalam lingkungan itu relatif

\footnotetext{
${ }^{12}$ Gagah Satria Utama, "Online Dispute Resolution: A Revolution In Modern Law Practice,"

Business Law Review, Vol. 3, No. 1 (2017), h. 2.

13 Moch. Basarah, Prosedur Alternatif Penyelesaian Sengketa Arbitrase Tradisional Dan Modern (Online), h. 92.

${ }^{14}$ Ethan Katsh and Janet Rifkin, Online Dispute Resolution: Resolving Conflicts in Cyberspace (San Francisco: Jossey-Bass, 2001), h. 2.
} 
sedikit komputer yang memiliki akses Internet. Sementara penggunaan internet saat ini adalah ssesuatu yang biasa. World Wide Web tidak ditemukan sampai tahun 1989 dan mungkin bahkan lebih signifikan National Science Foundation melarang kegiatan komersial dari Internet sampai tahun $1992 .^{15}$

Banyak penulis membagi ODR ke dalam 3 (tiga) periode yaitu sebelum dan hingga tahun 1995 (the elementary stage), periode sejak tahun 1995 sampai 1998 atau 1999 (the experimental stage) dan periode masa kini (entrepreneurial stage). ${ }^{16}$

\section{The Elementary Stage (sebelum dan hingga tahun1995)}

Sebelum 1995, hanya beberapa prosedur penyelesaian perselisihan sengketa yang diterapkan secara informal dalam konteks online tertentu. Hingga 1992, Internet sebagian besar berpusat di AS dan aktivitas komersial dilarang di bawah kebijakan penggunaan National Science Foundation yang dapat diterima negara itu. Jaringan ini digunakan terutama oleh akademisi untuk mengirim email dan berpartisipasi dalam listservs serta untuk bertukar file oleh orang-orang dengan keahlian teknis. ${ }^{17}$

Pada tahun 1992 National Science Foundation membuat keputusan untuk mencabut larangannya terhadap aktivitas komersial berbasis internet sangat kontroversial dan sangat signifikan. Setelah penghapusan larangan itu, perselisihan yang terkait dengan perdagangan online mulai muncul. Pada tahun 1994, misalnya, spam komersial pertama terjadi ketika dua pengacara mencoba merekrut klien untuk berpartisipasi dalam penipuan imigrasi. Beberapabulan kemudian, Komisi Perdagangan Federal AS mengajukan kasus pertamanya atas penipuan

${ }^{15}$ Ethan Katsh, "Online Dispute Resolution: Some Implications for the Emergence of Law in Cyberspace," Lex Electronica, vol.10 n`3 (Hiver/Winter, 2006), h. 3.

${ }^{16}$ Rafal Morek, Jurnal: "Regulation of Online Dispute Resolution: Between Law and Technology, 2005. http://www.odr.info/cyberweek/Regulation\%20of\%200DR_Rafal\% 20Morek.doc, diakses pada Minggu 12 Mei 2019, h. 9.

${ }_{17}$ lbid 
online. $^{18}$

Pada priode ini tidak ada banyak pertikaian, tetapi ada beberapa yang sangat menarik dan patut diperhatikan. berbagai mekanisme online digunakan untuk menangani konflik-konflik ini, tetapi tidak ada lembaga penyelesaian perselisihan terorganisir yang dikhususkan untuk ODR. ${ }^{19}$ Bahkan istilah ODR belum ditemukan.

\section{The Experimental Stage (sejak tahun 1995-1998/1999)}

Tahap kedua bertepatan dengan pertumbuhan Internet, khususnya sebagai media untuk perdagangan. Gagasan ODR muncul dari pertimbangan bahwa perselisihan akan berlipat ganda seiring dengan meningkatnya aktivitas online. Dengan demikian asal-usul ODR dilandasi pemikiran sederhana: semakin banyak transaksi online, semakin banyak perselisihan online. Dengan pertumbuhan jaringan, jenis-jenis perselisihan baru muncul, misalnya mengenai legalitas hubungan antar situs web, atau masalah kekayaan intelektual lainnya terkait dengan penggunaan dan penyalinan informasi. Bahkan semakin banyak Internet digunakan untuk tujuan apa pun, semakin banyak pula perselisihan yang muncul. Selama periode ini, pengakuan mulai tumbuh bahwa Internet memang membutuhkan beberapa institusi online yang fokus untuk mengatasi masalah yang timbul dengan frekuensi yang semakin meningkat.

Eksperimen perintis dalam ODR selama fase ini sebagian besar disponsori oleh akademisi dan lembaga nirlaba. Berbagai proyek dirancang untuk memungkinkan mereka yang terlibat dalam perselisihan mendapatkan penyelesaian tanpa harus bertemu. Misalnya, dalam kasus pertama yang dimediasi oleh Ombudsman Office Online, sebuah proyek mediasi online di University of Massachusetts, seorang mediator online membantu seorang pemilik situs web individu menyelesaikan masalah

\footnotetext{
${ }^{18}$ Ethan Katsh, Online Dispute Resolution: Some Implications for the Emergence of Law in Cyberspace, h. 3.

${ }^{19}$ Ethan Katsh and Janet Rifkin, Online Dispute Resolution: Resolving Conflicts in Cyberspace, h. 47.
} 
dengan sebuah koran lokal yang mengklaim pelanggaran hak cipta. ${ }^{20}$

\section{Entrepreneurial Stage (masa kini)}

Periode sejak tahun 1998 adalah masa dimana industri ODR mulai muncul. Telah ada pengakuan oleh kepentingan pemerintah dan komersial bahwa sumber daya online dapat menjadi solusi bagi banyak masalah yang berasal dari lingkungan online. Tidak seperti tiga atau empat tahun sebelumnya, sekarang ODR lebih diterima dan memang diinginkan untuk menjadi pilihan pertama dalam proses penyelesaian perselisihan yang muncul dari kegiatan online. Selain itu telah diakui bahwa teknologi yang bekerja untuk menyelesaikan perselisihan online juga dapat digunakan secara efisien untuk perselisihan offline. ${ }^{21}$

Meskipun membutuhkan biaya tinggi untuk membangun dan menerapkan sistem ODR, jumlah perusahaan yang menawarkan beberapa bentuk ODR terus bertambah. Konsekuensinya, menyimpulkan, telah ada pengakuan yang berkembang baik oleh kepentingan pemerintah maupun komersial bahwa sumber daya online dapat menjadi solusi bagi banyak masalah yang berasal dari lingkungan online. ${ }^{22}$ Adapun bentuk dari ODR adalah:

1) Online Negotiation

Adapun pengertian negosiasi dalam system penyelesaian sengketa melalui ODR, adalah:

"Negotiation, where parties try to work out their dispute between themselves without outside assistance. Negotiations happen all the time but online certain tool and techniques can provide structure to negotiations so that it's easier to reach a better resolution in lesstime."

Dalam penyelesaian sengketa melalui negosiasi secara online terdapat 2 pendekatan yang dapat dilakukan, antara lain:

a) Assisted Negotiation

\footnotetext{
20 Ibid

${ }^{21}$ Opcit, h. 47-48

22 Opcit, h. 11.
} 


\section{b) Automated Negotiation}

Bantuan negosiasi (Assisted Negotiation) yang disebut juga dengan enhanced negotiation atau technologically facilitated negotiation dengan metoda ini para pihak akan dibantu untuk mencapai kesepakatan melalui komunikais secara langsung dengan menggunakan the aid of threaded message board system, metoda penyimpanan data, pengaturan alat untuk pertemuan secara online, dan alat teknologi informasi lainnya selain $e$ mail.

Assisted Negotiation merupakan metoda yang paling mudah dari ODR, karena para pihak yang bersengketa dapat bernegosiasi secara langsung melalui media online yang disediakan. Selain itu, komunikasi antara para pihak yang bersengketa dilakukan melalui media dan peraturan-peraturan yang sudah ditentukan oleh provider. Provider dari metoda ini, seperti: square trade, online confidence, ECODIR, online resolution, resolution forum, and the claim room.

Negosiasi secara otomatis (Automated Negotiation) merupakan perkembangan dari Online Despute Resolution, yang mana proses penyelesaian sengketa seluruhnya dikendalikan secara otomatis melalui software. Metoda Automated Negotiation atau yang dikenal dengan blindbidding negotiation ini melibatkan para pihak untuk menggambarkan cakupan sengketa dan menyampaikan penawaran serta permintaan dalam bentuk penyelesaian tawar-menawar melalui computer yang terjamin keamanannya, yaitu dengan password yang dilindungi dan webbased platform. Metoda ini merupakan salah satu metoda yang banyak tersedia, dan banyak digunakan dalam penyelesaian sengketa asuransi. Provider dari Automated negotiation, misalnya: ClickNsettle. Cybersettle, Intersettle, e-settle.co.uk, MARS, Settlement Online, WeCansettle, The Claim Room, WebMediate and Dispute Manager. ${ }^{23}$

2) Online Mediation

23 Moch. Basarah, Prosedur Alternatif Penyelesaian Sengketa Arbitrase Tradisional Dan Modern (Online), h.114-115. 
Mediasi merupakan suatu penyelesaian sengketa berdasarkan perundingan yang melibatkan pihak ketiga, atau yang dikenal dengan mediator, untuk membantu para pihak yang bersengketa untuk mencari penyelesaian sengketa, yang mana mediator tidak mempunyai kewenangan untuk membuat keputusan selama proses perundingan berlangsung. Oleh karena itu, dalam penyelesaian sengketa melalui mediasi, pihak ketiga merupakan pihak yang bersifat netral. namun berperan serta secara aktif sebagai perantara suatu penyelesaian sengketa antara para pihak. Tugas utama seorang mediator adalah untuk membantu para pihak mengadakan pembicaran, bukan sebagai pembuat keputusan.

Proses penyelesaian sengketa melalui mediasi secara online tidak berbeda jauh dengan penyelesaian sengketa melalui mediasi secara tradisional. Perbedaannya adalah pada pemanfaatan teknologi. Pemanfaatan teknologi yang dimaksud bukanlah sebatas penggunaan $e$ mail untuk melakukan diskusi oleh karena mediator tradisional juga sudah dapat menggunakan e-mail dalam proses penyelesaian sengketanya.

Pada mediasi online, provider menyediakan alat komunikasi yang dapat mengintegrasikan e-mail dengan alat komunikasi lainnya, seperti electronic conference, online chat, video conferencing, faximile, dan telepon. Bahkan beberapa provider dapat mengatur pertemuan para pihak secara langsung apabila diperlukan dan kondisi yang memungkinkan. Selain itu, perbedaan utama antara penyelesaian sengketa melalui mediasi secara tradisional dan online, adalah dalam penyelesaian sengketa mediasi secara tradisional para pihak memiliki hubungan yang berkelanjutan. Hubungan ini merupakan harapan dari para pihak, oleh karenanya mereka memeliharn hubungan berkelanjutan ini dengan baik dengan jalan memilih cara penyelesaian sengketa melalui mediasi. Namun, dalam penyelesaian sengketa mediasi online umumnya para pihak sebelumnya tidak mempunyai hubungan yang berkelanjutan, pilihan penyelesaian sengketa melalui mediasi online dilakukan para pihak 
karena mereka tidak perlu hadir secara langsung (face to face), biayanya murah dan dapat diakses di mana saja. Selain itu penyelesaian sengketa mediadi online hanya didasarkan atas komunikasi secara tertulis melalui sistem password yang dilindungi. Dalam penyelesaian sengketa melalui mediasi online dikenal bentuk mediasi klasik yang disebut three room procedure.

Dalam bentuk mediasi ini mediator berbicara dengan salah satu pihak dalam suatu ruangan rahasia yang terpisah dan setelah itu para pihak merundingkannya kembali dalam ruangan yang ketiga. Three room procedure ini dapat disimulasikan dalam dunia nyata melalui tiga password yang dilindungi dengan chatrooms Dalam metoda mediasi Three room procedure, tahap pertama untuk memulai proses penyelesaian sengketa dengan mediasi adalah menampung permasalahan para pihak. Kemudian berdasarkan masalah tersebut, mediator akan menyampaikan informasi kepada para pihak dan meminta kesiapannya untuk menjadi bagian dalam penyelesaian sengketa tersebut. Biasanya kesepakatan penyelesaian sengketa dengan mediasi ini telah disiapkan, dan akan ditandatangani para pihak, jika penyelesaian sengketa dengan medisi berjalan dengan sukses, maka para pihak akan menandatangani perjanjian penyelesaian sengketa. Setelah proses mediasi selesai dan sukses, mediator dapat memberi rekomendasi akhir kepada para pihak, tetapi rekomendasi ini sifatnya tidak mengikat. Karena alasan ini, penyelesaian sengketa melalui mediasi dapat dikatakan sebagai proses penyelesaian sengketa secara fakultatif. Para pihak dapat mengambil jalannya masing-masing setiap saat sebelum perjanjian penyelesaian sengketa ditandatangani. ${ }^{24}$

3) Online Arbitration

Selain negosiasi dan mediasi online, dalam ODR dapat digunakan penyelesaian sengketa melalui arbitrase. Proses penyelesaian sengketa melalui arbitrase lebih formal jika dibandingkan dengan metoda ${ }^{24}$ Ibid, h.115-118. 
penyelesaian sengketa lainnya yang bersifat extra judicial. Arbiter dapat mengeluarkan keputusan yang mengikat berdasarkan pertimbangan dan bukti-bukti yang diajukan para pihak. Dalam arbitrase online proses dengar pendapat, pengajuan bukti-bukti, dan sebagainya didasarkan pada dokumen tertulis, jika diharuskan adanya pertemuan face to face maka dapat digunakan fasilitas video conferencing. Secara umum, penyelesaian sengketa melalui arbitrase secara online lebih rumit jika dibandingkan dengan proses penyelesaian sengketa lainnya, seperti negosiasi dan mediasi online. Proses arbitrase online berlangsung melalui tahapan yang berbeda satu lainnya, meliputi: persetujuan/ kesepakatan, pemilihan proses, penyajian permasalahan, penyangkalan, pertimbangan, dan putusan. Sama halnya dengan arbitrase online yang juga menggunakan jasa pihak ketiga yang netral sebagai pembuat keputusan. Hanya saja, di dalam arbitrase online terdapat pihak keempat (the fourth party) yaitu teknologi yang membantu arbiter dalam melaksanakan tugasnya. Adapun pengertian arbitrase online adalah:

"Arbitration, where parties make their case to a neutral party who does have decision making authority. Arbitration works like a courtroom, the arbitrator is like a judge, and after hearing both sides renders a decision. This decision can be either binding or non-binding, depending on what the parties agree to before take arbitration take place."

Berdasarkan pengertian tersebut, maka putusan arbitrase dapat bersifat binding atau non-binding tergantung kepada kesepakatan para pihak sebelum putusan itu dilaksanakan. Dengan demikian, arbitrase online terbagi menjadi 2 bentuk yaitu: arbitrase yang mengikat dan arbitrase yang tidak mengikat. Bentuk arbitrase yang tidak mengikat (nonbinding arbitration), terbagi lagi menjadi 2 bentuk, yaitu: pertama optionally binding dan kedua truly namun optionally binding berdasarkan kesepakatan para pihak dapat bersifat mengikat. Sedangkan truly nonbinding tidak dapat menghasilkan suatu putusan yang mengikat.Dalam arbitrase online, terdapat beberapa hal yang sangat penting untuk 
diperhatikan, antara lain: Perjanjian arbitrase, prosedur arbitrase, dan putusan arbitrase. $^{25}$

\section{Kesimpulan}

1. Faktor-faktor yang menyebabkan besarnya potensi sengketa $E$ Commerse antara lain:

a. Dalam transaksi Elektronik sering kali tidak sesuai dengan Undang-undang No. 11 Tahun 2008 dan Undang-Undang No. 19 Tahun 2016 Tentang Informasi dan Transaksi Elektronik (yang selanjutnya disingkat UU ITE) dan Peraturan Pemerintah No. 82 Tahun 2012 tentang Penyelenggaraan Sistem dan Transaksi Elektronik (yang selanjutnya disingkat PP PSTE).

b. Karena sifat internet yang tidak mengenal batas negara dan tidak bisa dikontrol, maka permasalahan yang timbul dalam hal penge-naan pajak terhadap e-commerce cukup rumit, diantaranya: siapa yang berhak memungut pajak? Jika terjadi transaksi baik barang atau jasa lintas negara, maka siapa yang berhak memungut pajak menjadi tidak jelas.

c. Karena sifat internet yang tidak bisa dikon-trol dan memungkinkan anonimitas, maka akan sangat sulit untuk melacak transaksi yang terjadi Kalaupun ada pihak yang ingin mengetahuinya seperti pemerintah sebagai pemungut pajak, ada masalah lain di belakangnya yaitu tidak adanya bukti transaksi secara fisik sebagai bukti audit

d. Tidak adanya Undang-undang global mengatur Internet yang merupakan sarana informasi global sampai saat ini belum mempunyai perangkat peraturan yang diterima oleh semua pengguna. Hal ini disebabkan adanya perbedaan undangundang yang bersifat lokal.

\footnotetext{
${ }^{25}$ Ibid h.118-120.
} 
2. Online Dispute Resolution sendiri memiliki 3 bentuk penyelesaian sengketa yaitu online negotiation, online mediation, dan online arbitration. Perbedaan antara ODR dan Alternative Dispute Resolution (ADR) terletak pada pelaksanaannya yang dilakukan secara online. Konsep ODR memang belum diatur secara rinci dan tegas, namun bukan berarti ODR tidak dapat diperlakukan di Indonesia, karena Indonesia memberikan kebebasan berkontrak dan kebebasan untuk memilih forum penyelesaian sengketa mana yang akan dipakai untuk menyelesaikan sengketanya. Hal ini dapat dilihat pada Pasal 1338 KUH Perdata dan pada Pasal 18 UndangUndang Nomor 11 Tahun 2008 tentang Informasi dan Transaksi Elektronik. Selain itu dalam Pasal 5 ayat (3) PERMA No. 1 tahun 2016 tentang Prosedur Mediasi di Pengadilan terdapat isyarat bahwa pelaksaan mediasi online dapat dilakukan. Sedangkan menurut Undang-Undang Nomor 30 Tahun 1999 Tentang Arbitrase dan Alternatif Penyelesaian Sengketa, celah untuk melakukan arbitrase online dapat dilihat dari ketentuan pada Pasal 4 ayat (3). Dokumen elektronik dan sahnya suatu dokumen serta tanda tangan elektronik, telah diatur dalam Undang-Undang ITE Pasal 5.

\section{DAFTAR PUSTAKA}

Agus Yudha Hernoko, Hukum Perjanjian Asas Proporsionalitas Dalam Kontrak Komersial, Jakarta: Kencana, 2010.

Andina Librianty, Ketimbang Sibuk Bersaing, Shopee Utamakan Layanan Konsumen,

Efa Laela Fakhriah, Bukti Elektronik Dalam Pembuktian Perdata, Bandung: PT Alumni, 2011

Eman Suparman, Pilihan Forum Arbitrase dalam Sengketa Komersil untuk Penegakan Keadilan(Jak arta: Tatanusa, 2004) 
Ethan Katsh and Janet Rifkin, Online Dispute Resolution: Resolving Conflicts in Cyberspace (San Francisco: Jossey-Bass, 2001)

Fadhly Fauzi Rahman, Transaksi E-Commerce RP 250 T, Mendag: RI Punya Kekuatan Perdagangan Digital Global, https://finance.detik.com diakses pada tanggal 07 September 2019 pukul 00:45

Fauyhi Eko Nugroho, Perancangan Sistem Informasi Penjualan Online Studi Kasus Tokoku, Jurnal Simetris Vol. 7 No 2 November, Tangerang: Universitas Muhammadiyah Tangerang, 2016, Gagah Satria Utama, "Online Dispute Resolution: A Revolution In Modern Law Practice," Business Law Review, Vol. 3, No. 1 (2017), h. 2. http://tekno.liputan6.com diakses pada tanggal 07 September 2019 pukul 01:02.

M. Agus Yozami, Rujukan Aturan Perundang-Undangan Bagi Konsumen Yang Dirugikan Online Shop Pemerintah Sudah Saatnya Mengesahkan Rancangan Peraturan Pemerintah (RPP) Tentang Perdagangan Elecktronik Yang Menjadi Payung Teknis Untuk Operasional Belanja Online, www.hukumonline.com diakses pada tanggal 07 September 2019 pukul 01:21

Marilyn Greenstein and Miklos Vasarhelyi, Electronic Commerce (New YPork McGraw Hill, 2002)

Moch. Basarah, Prosedur Alternatif Penyelesaian Sengketa Arbitrase Tradisional Dan Modern (Online)

Pablo Cortés, "What is Online Dispute Resolution?," CSLS Oxford (Oktober, 2011)

Prof. Drs. C.S.T. Kansil,SH dan Christine S.T. Kansil, S.H., M.H,PokokPokok Pengetahuan Hukum Dagang Di Indonesiaedisi Kedua,Sinar Grafika,2002

Rafal Morek, Jurnal: "Regulation of Online Dispute Resolution: Between Law and Technology, 2005. 
http://www.odr.info/cyberweek/Regulation\%20of\%20ODR_Rafal\% 20Morek.doc, diakses pada Minggu 12 Mei 2019, h. 9. 